\title{
Population Dynamic of Olive Black Scale, Saissetia oleae (Olivier) (Hemiptera: Coccidae) Infesting Olive Trees in Irrigated Farms in Matrouh Governorate, Egypt
}

\author{
Mesbah, H. A. ${ }^{1}$, Kh. S. Moursi ${ }^{2}$, Magda B. EL-Kady ${ }^{1}$, \\ A. A. M. Abdel-Megeed ${ }^{1}$ and Aml Ghaith ${ }^{1,3}$ \\ ${ }^{1}$ Department of Plant Protection, Faculty of Agriculture (Saba Basha), Alexandria \\ University. \\ ${ }^{2}$ Agricultural Research Center, Plant Protection Institute, Sabhia, Alexandria \\ ${ }^{3}$ Department of Zoology., Faculty of Arts and Sciences (Darna), Omar El-Mokhtar, \\ University, Libya.
}

\begin{abstract}
The present study was carried out in Matrouh Governorate during two successive years (February, 2017- February, 2019) to investigate the population density, population age structure, number of generations, seasonal variation and effect of three weather factors (temperature, relative humidity and wind speed) on olive black scale, S. oleae infesting olive trees under irrigation system. Results concerning the fortnightly variations of the total monthly counted individuals of $S$. oleae $/ 5$ trees throughout the period of study revealed the presence of six variation periods in two successive years, three in spring months and three in summer months. Considering the population age structure, the immature stage was $83.3 \%$ in $15^{\text {th }}$ February, , decreased to the minimum of $54.4 \%$ of total count in $15^{\text {th }}$ September, then the population was increased to constitute a large ratio during autumn and winter months in the first and second growing seasons. The adult females population started with $11.5 \%$ of the total counted individuals in the first season, increased or/and decreased in the next months to reach the maximum of $23.3 \%$ in $1^{\text {st }}$ September, then decreased in autumn and winter months. In the second season, the population took the same trend with slight difference in numbers. The gravid female population was more or less higher in March to July in both two growing seasons. The black olive scale has two generations/year according to the immature stage appearance. The first peak of immature stage individuals was recoded in June and the second in August. The seasonal variations in population densities can be ascendingly arranged as, winter, autumn, spring and summer months. The assessed simple correlation values of three weather factors (daily mean temperature, relative humidity and wind speed) with total count of S. oleae individuals were calculated. Temperature was found to have a positive significant effect on the population, while the relative humidity had an insignificant effect. Wind speed had a positive effect on population density of the olive black scale, (S. oleae).
\end{abstract}

\section{INTRODUCTION}

Family Coccidae is the third largest family of Coccoidea, with about 1138 sp. belonging to 160 genera worldwide (Ben-Dov et al., 2010). At the present time, some 10 subfamilies are recognized (Hodgson, 1994). In Egypt this family is the third family of super family Coccoidae in the collection of the Egyptian ministry of Agriculture (Mohammad and Ghabbour, 2008). It is presented with 28 species belonging to 15 genus and three subfamilies; Ceroplastinae 
Atkinson, Coccinae Fallen, and Filippiinae Bodenheimer. The Mediterranean black scale, Saissetia oleae (Olivier) (Hemiptera: Coccidae) was recorded in Egypt by Hall (1922). It is found in most Mediterranean countries (Bodenheimer, 1951; Habar and Mifsud, 2007). It is a polyphagous species that can occur on several host plants which is considered one of the most important pests on olive and citrus trees (Morillo, 1977; Ben-Dov and Hedgson, 1997). According to Haniotakis (2005) black scale is considered as a major secondary insect-pest, causing damages of major economic importance. The damages are produced when large populations are present and their feeding can cause physiological damage to the host plant through the increase of the transpiration rate and by depletion of nutrients (Delrio and Foxi, 2010).

In Algeria, Ilias and Hammadi (2017) reported that the density of Saissetia oleae populations has varied from year to year and from region to region. Populations peaked in June, when crawlers emerged after the egglaying period, and decreased during several months. In Egypt, Saissetia oleae was observed in both dry and irrigated farms on olive trees all over the year causing great damage to the infested trees (Badary, 2010 and Boulabiad, 2010). Therefore, the present investigation was carried out to study some ecological aspects on Olive black scale infesting olive trees under irrigated farms.

\section{MATERIALS AND METHODS}

The study was started in mid-February, 2017 to $1^{\text {st }}$ February, 2019 in Matrouh Governorate in olive farm under irrigation system. Five trees were chosen to study the population density and population age structure, as well as the effect of three weather factors (temperature, relative humidity and wind speed) on the olive black scale, Saissetia oleae (Olivier). From each tree, 10 leaves and five small branches $(15 \mathrm{~cm})$ were picked out every two weeks from each direction of the tree. Leaves and branches were put in cloth bags and transferred to the laboratory for counting using a stereoscopic binocular microscope where upper and lower surfaces of both leaves and branches were examined. Immature and mature female stages were counted and recorded.

The weather factors (daily mean temperature $\left[{ }^{\circ} \mathrm{C}\right]$, mean relative humidity [\%] and wind speed [m/sec]) were considered to determine their effect on the populations of Saissetia oleae. Daily records of these weather factors were obtained from Nasa/Power SRB/ FLASHF 10x /MERRAA2/GEOS, Table (1). For statistical analysis, simple correlation ( $r$ ) and partial regression (b) values were calculated to obtain information about the relationship between the number of individuals and mean records of these three tested weather factors. The increase of the detected insect densities was calculated by dividing the total number of recorded individuals at one sampling date over its preceding one. 
Table (1). Fortnightly variation of three climatic factors (Temperature ${ }^{\circ} \mathrm{C}$, $\mathrm{RH} \%)$ and wind speed $(\mathrm{m} / \mathrm{sec})$ at matrouh govenorate, Egypt

\begin{tabular}{lcccccc}
\hline \multirow{2}{*}{ Month } & \multicolumn{2}{c}{$\begin{array}{c}\text { Average } \\
\text { temperature (C) }\end{array}$} & \multicolumn{2}{c}{ Humidity (\%) } & \multicolumn{2}{c}{ Wind Speed (m/sec) } \\
\cline { 2 - 7 } & $2017 / 18$ & $2018 / 19$ & $2017 / 18$ & $2018 / 19$ & $2107 / 18$ & $2018 / 19$ \\
\hline Feb.15 & 13.8 & 14.9 & 70.1 & 77.7 & 5.0 & 5.0 \\
Mar.1 & 15.6 & 15.6 & 68.2 & 66.8 & 7.6 & 4.3 \\
Mar.15 & 17.2 & 17.8 & 67.5 & 68.2 & 4.5 & 3.9 \\
Apr.1 & 16.8 & 16.1 & 68.7 & 65.5 & 6.0 & 6.9 \\
Apr.15 & 25.5 & 24.8 & 64.5 & 64.6 & 6.8 & 6.8 \\
May.1 & 24.8 & 24.0 & 62.5 & 56.7 & 5.9 & 5.6 \\
May.15 & 23.6 & 23.0 & 72.1 & 72.1 & 3.9 & 3.3 \\
Jun.1 & 32.9 & 31.2 & 68.1 & 68.0 & 3.5 & 8.5 \\
Jun.15 & 31.2 & 31.2 & 61.2 & 61.0 & 5.1 & 5.5 \\
Jul.1 & 33.4 & 33.4 & 64.8 & 69.5 & 4.8 & 4.8 \\
Jul.15 & 34.3 & 34.3 & 70.3 & 70.3 & 4.7 & 4.9 \\
Aug.1 & 31.5 & 32.0 & 59.8 & 58.5 & 5.5 & 5.7 \\
Aug.15 & 33.5 & 33.0 & 75.4 & 72.3 & 6.3 & 6.7 \\
Sep.1 & 30.1 & 30.1 & 66.7 & 60.4 & 5.4 & 5.4 \\
Sep.15 & 29.5 & 28.5 & 53.9 & 54.5 & 3.7 & 3.7 \\
Oct.1 & 24.5 & 26.1 & 69.9 & 75.4 & 4.1 & 6.1 \\
Oct.15 & 26.0 & 25.0 & 67.8 & 53.6 & 6.1 & 5.1 \\
Nov.1 & 23.6 & 23.1 & 68.8 & 63.5 & 5.7 & 4.1 \\
Nov.15 & 20.5 & 20.5 & 69.4 & 69.0 & 6.8 & 4.9 \\
Dec.1 & 21.2 & 20.0 & 80.0 & 82.1 & 3.8 & 3.8 \\
Dec.15 & 16.9 & 18.2 & 79.9 & 81.5 & 5.2 & 5.7 \\
Jan.1 & 16.1 & 16.0 & 60.8 & 59.9 & 3.8 & 3.4 \\
Jan.15 & 12.3 & 16.2 & 62.2 & 62.2 & 4.5 & 3.5 \\
Feb.1 & 13.5 & 13.5 & 65.7 & 66.2 & 4.2 & 5.0 \\
\hline
\end{tabular}

\section{RESULTS AND DISCUSSION}

Data presented in Table (2) and illustrated in Figures (1 and 2) show the counted individuals of $S$. oleae infesting olive tree in Matrouh governorate during the period of study (2017-2019). It is revealed that the total counted individuals decreased or/and increased during March and April months of the first growing season, then increased in the following months to reach the maximum of 4055 individuals in late June resembling $9.7 \%$ of grand total. The population redeceased in July and reincreased in August to 4077 individuals representing $9.8 \%$ of grand total, then redeceased gradually till late January to a minimum of 212 individuals ( $0.5 \%$ of total counted individuals).

The population started to increase again in early February, 2018. In the second growing season, a merely similar trend of population fluctuation was also detected (Table 2 \& Fig. 2). Herein, from the above mentioned results it could be seen that the estimated densities of fluctuating population of $S$. oleae on olive trees throughout both the following growing seasons showed two distinctly prominent peaks for each season. 
Table (2).Fortnightly variation in population count of Saissetia oleae infesting olive trees during the periods of (201718)and \{2018-19)in Matrouh Governorate

\begin{tabular}{|c|c|c|c|c|c|c|c|c|c|c|c|c|}
\hline \multirow[t]{2}{*}{ Sampling dates } & \multicolumn{2}{|c|}{$\begin{array}{c}\text { Total No. of } \\
\text { individuals/ } \\
5 \text { trees }\end{array}$} & \multicolumn{2}{|c|}{$\begin{array}{l}\text { Quotation of } \\
\text { increase }\end{array}$} & \multicolumn{2}{|c|}{$\begin{array}{l}\% \text { of grand total } \\
\text { count }\end{array}$} & \multicolumn{2}{|c|}{$\begin{array}{l}\% \text { of inspected } \\
\text { immature }\end{array}$} & \multicolumn{2}{|c|}{$\begin{array}{l}\% \text { of inspected } \\
\text { adult females }\end{array}$} & \multicolumn{2}{|c|}{$\begin{array}{l}\% \text { of inspected } \\
\text { gravid females }\end{array}$} \\
\hline & $2017 / 18$ & $2018 / 19$ & $2017 / 18$ & $2018 / 19$ & $2017 / 18$ & $2018 / 19$ & $2017 / 18$ & $2018 / 19$ & $2017 / 18$ & $2018 / 19$ & $2017 / 18$ & $2018 / 19$ \\
\hline $15^{\text {nd. }}$ & 868 & 879 & - & - & 2.1 & 2.1 & 83.3 & 85.0 & 11.5 & 10.0 & 5.2 & 5.0 \\
\hline $1^{\text {st }}$ Mar & 683 & 690 & 0.7 & 0.8 & 1.6 & 1.6 & 84.2 & 86.2 & 12.3 & 8.7 & 3.5 & 5.1 \\
\hline $15^{\text {nd }} \cdot$ Mar & 1000 & 1007 & 1.4 & 1.5 & 2.4 & 2.4 & 81.5 & 82.8 & 9.6 & 7.9 & 8.9 & 9.2 \\
\hline $1^{\text {st }} \cdot \mathrm{Apr}$ & 838 & 845 & 0.8 & 0.8 & 2.0 & 2.0 & 77.2 & 78.8 & 12.2 & 10.6 & 10.6 & 10.4 \\
\hline $15^{\text {nd }}$ Apr & 967 & 475 & 1.2 & 1.1 & 3.3 & 2.3 & 74.0 & 75.6 & 14.9 & 13.4 & 11.1 & 10.9 \\
\hline $1^{\text {st }}$. May & 1220 & 1228 & 1.3 & 0.3 & 2.9 & 2.9 & 74.7 & 75.8 & 12.8 & 12.3 & 12.5 & 11.9 \\
\hline $15^{\text {nd }}$. May & 2668 & 2676 & 2.2 & 2.2 & 6.4 & 6.4 & 74.8 & 75.4 & 12.4 & 12.5 & 12.8 & 12.1 \\
\hline $1^{\text {s.t. }}$ Jun & 3764 & 3771 & 1.5 & 1.4 & 9.0 & 9.0 & 68.7 & 69.2 & 19.1 & 15.7 & 12.1 & 15.1 \\
\hline $15^{\text {nd }}$. Jun. & 4055 & 4063 & 1.0 & 1.1 & 9.7 & 9.7 & 63.5 & 63.8 & 21.2 & 19.2 & 15.3 & 17.0 \\
\hline $1^{\text {st }} . J u l$ & 3808 & 3815 & 1.0 & 0.9 & 9.1 & 9.1 & 65.1 & 65.5 & 15.5 & 18.0 & 19.4 & 16.5 \\
\hline $15^{\text {nd }}$. Jul & 3488 & 3447 & 1.0 & 0.9 & 8.4 & 8.3 & 67.1 & 67.6 & 18.2 & 15.8 & 14.7 & 16.6 \\
\hline $1^{\text {st }}$. Aug & 4077 & 4085 & 1.2 & 1.2 & 9.8 & 9.7 & 69.9 & 70.1 & 16.8 & 14.7 & 13.7 & 15.2 \\
\hline $15^{\mathrm{nd}} \cdot$ Aug & 3345 & 3353 & 0.9 & 0.8 & 8.0 & 8.0 & 64.1 & 64.6 & 18.6 & 18.2 & 17.2 & 17.2 \\
\hline $1^{\text {st }}$ Sep & 3235 & 3242 & 0.9 & 1.0 & 7.8 & 7.7 & 57.9 & 58.4 & 23.3 & 21.1 & 18.7 & 20.5 \\
\hline $15^{\text {nd }}$ Sep. & 2468 & 2475 & 0.7 & 0.8 & 5.9 & 5.9 & 54.4 & 53.1 & 23.5 & 24.2 & 24.1 & 22.7 \\
\hline $1^{\text {st }}$. Oct & 1138 & 1146 & 0.5 & 0.5 & 2.7 & 2.7 & 85.9 & 87.0 & 4.0 & 7.4 & 10.2 & 5.6 \\
\hline $15^{\text {nd }}$. Oct & 1010 & 1018 & 0.9 & 0.8 & 2.4 & 2.4 & 90.5 & 91.8 & 3.9 & 5.0 & 5.6 & 3.1 \\
\hline $1^{\text {st }}$. Nov & 863 & 869 & 0.9 & 0.8 & 2.1 & 2.1 & 91.4 & 93.0 & 3.4 & 4.3 & 5.2 & 2.8 \\
\hline $15^{\text {nd }} \cdot$ Nov & 606 & 614 & 0.7 & 0.7 & 1.5 & 1.5 & 92.4 & 94.5 & 3.3 & 3.1 & 4.3 & 2.4 \\
\hline $1^{\text {st }}$. Dec & 484 & 496 & 0.8 & 0.8 & 1.2 & 1.2 & 91.0 & 93.7 & 3.9 & 3.6 & 5.1 & 2.7 \\
\hline $15^{\text {nd }} \cdot$ Dec & 298 & 305 & 0.6 & 0.6 & 0.7 & 0.7 & 93.3 & 94.7 & 4.7 & 2.9 & 5.0 & 2.3 \\
\hline $1^{\text {st }}$ Jan & 251 & 249 & 0.9 & 0.8 & 0.6 & 0.6 & 93.2 & 92.4 & 3.6 & 4.0 & 3.2 & 3.6 \\
\hline $15^{\text {nd }} . J a n$ & 212 & 142 & 0.8 & 0.7 & 0.5 & 0.5 & 95.1 & 95.3 & 1.9 & 1.6 & 2.4 & 3.1 \\
\hline $1^{\text {st }} \cdot$ Feb & 396 & 374 & 1.9 & 1.8 & 1.0 & 0.9 & 47.5 & 96.5 & 1.5 & 2.4 & 1.0 & 1.1 \\
\hline Grand total year & 41747 & 41264 & - & - & - & - & - & - & - & - & -- & - \\
\hline
\end{tabular}




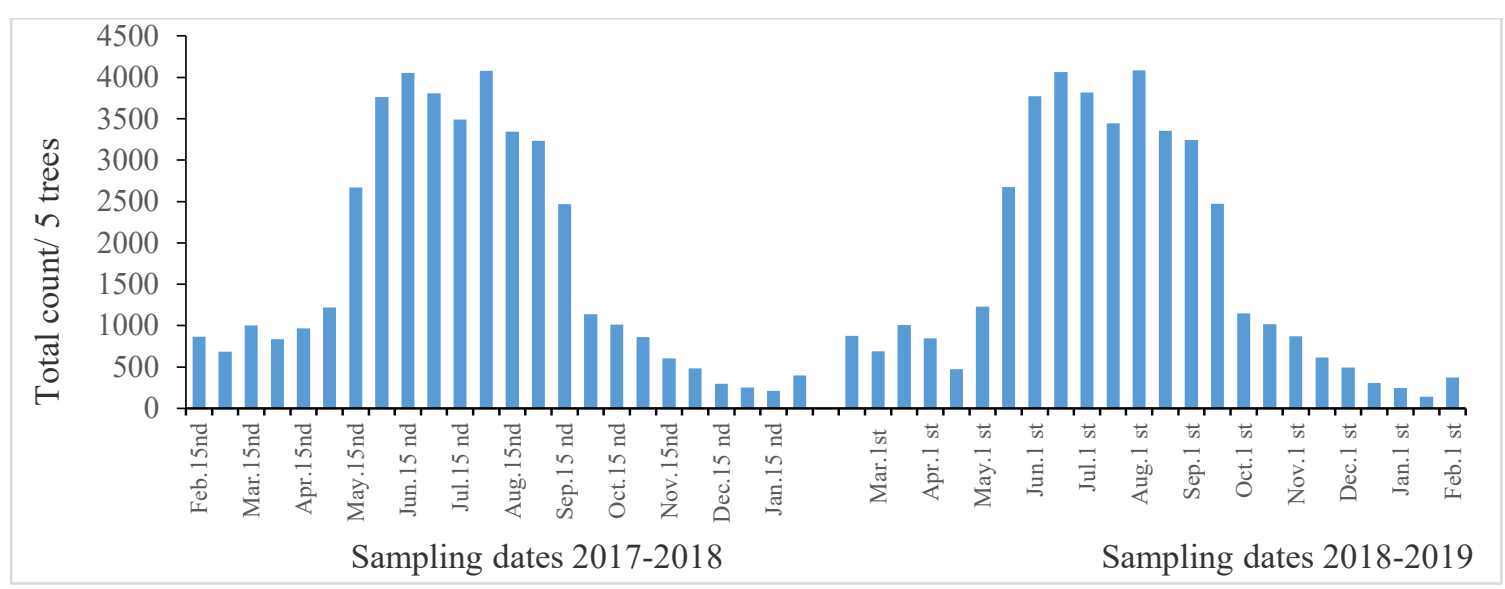

Fig. (1). Fortnightly variation of total count of $S$. oleae detected on olive trees during $2017 / 2018$ and $2018 / 2019$ seasons

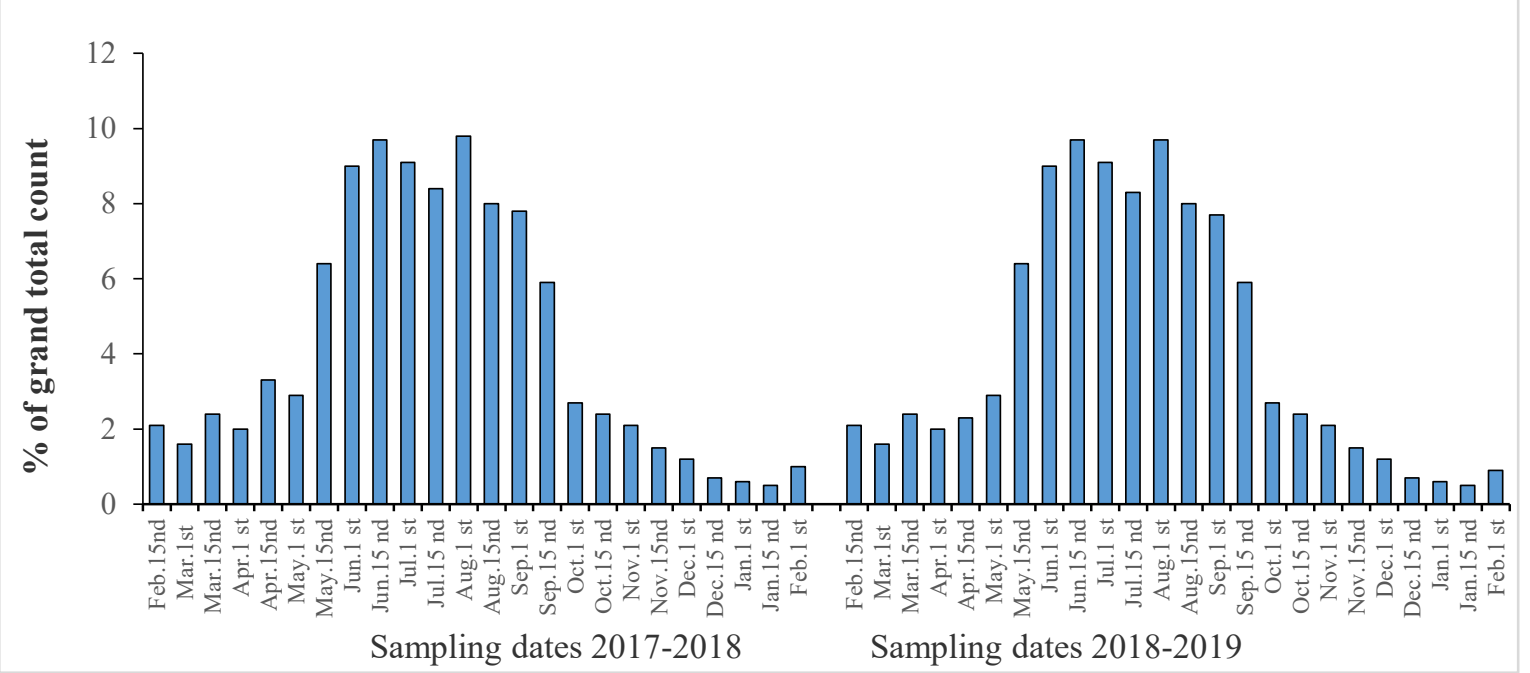

Fig (2) . Fortnightly variation of grand total count of S. oleae detected on olive trees during $2017 / 2018$ and $2018 / 2019$ seasons

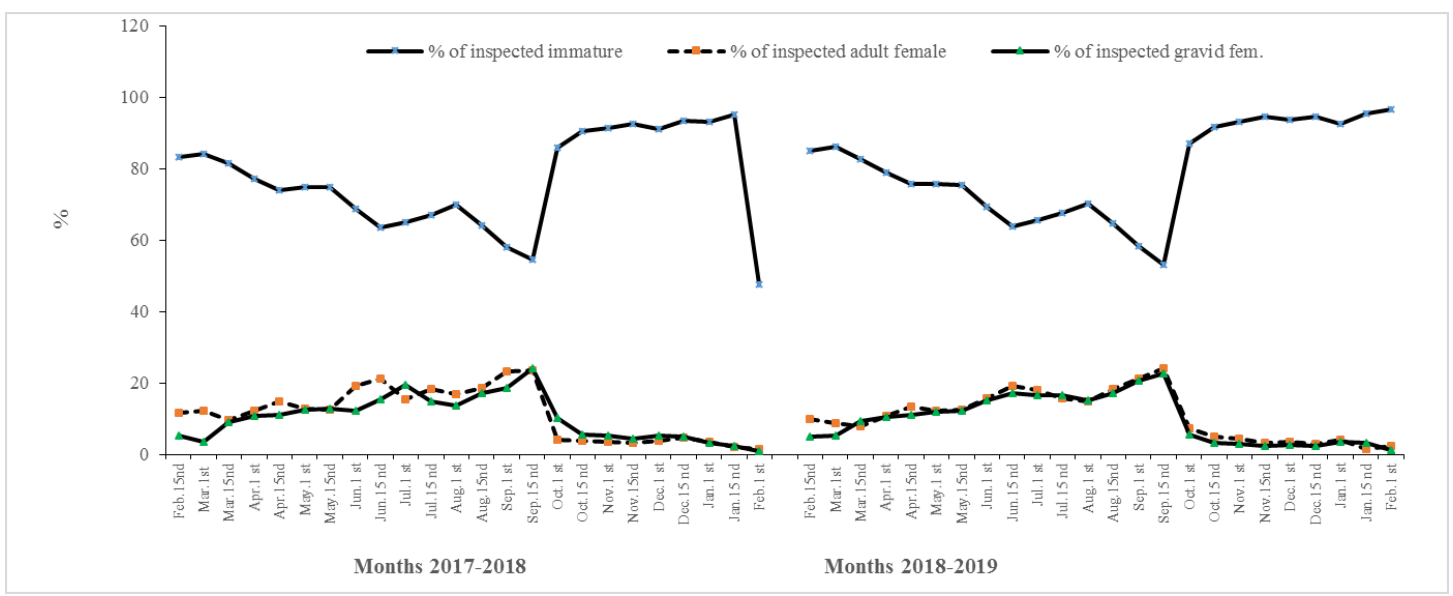

Fig. (3). Fortnightly variations calculated as percentages of inspected immature, adult and gravid females of $S$. oleae infesting olive trees during $2017 / 2018$ and $2018 / 2019$ seasons 
They are extended from late May to early October with high counted individuals in $15^{\text {th }}$ June \& $1^{\text {st }}$ August (4055 \& 4077 and $4063 \& 4085$ ) individuals in both experimental seasons, respectively resembling $9.7 \& 9.8 \%$ of total counted individuals in both two growing seasons).

Results concerning the fortnightly variation (quotation of increase) (Q.I) in the total monthly counted individuals of $S$. oleae/ 5 trees through the period of study revealed the presence of six variation periods in both growing seasons, three in spring months (March, April and May) and three in summer months (June, July and August). The highest value of individual increase was observed in late May in both two experimental seasons $(2018$ \& 2019). These results are in agreement with those reported by Barreda (2007) who reported that there was one important peak of the black scale population in July.

Considering the population age structure, the obtained results presented in Table (2) show that percentage of immature stage was $83.3 \%$ of total count in late February, then it was decreased in the following months to reach the minimum in late September (54.4\% of total count). Immature stage was increased to constitute large ratio during autumn and winter months in the first growing season. Similar trend of results was also observed in the second year. Concerning the population density of adult females, the detected numbers were less than those of immature stage throughout the two successive years. The adult females were $11.5 \%$ of total monthly counted individuals in $15^{\text {th }}$ February and increased to $12.3 \%$ in early March, then decreased or/and increased in the following months to reach the maximum of $23.5 \%$ in $15^{\text {th }}$ September, redecreased to the minimum in autumn and winter months in the first growing season. The population of adult females took the same trend in the second growing season with slight difference in percentage of total count (Table 2).

The incidence of gravid females was more or less higher in March, April, May, June and July. In early March the percentage of gravid females reached $3.5 \%$ of the monthly counted individuals, then it increased gradually to maximum of $19.4 \%$ in $1^{\text {st }}$ July (of the first season), then the total count of gravid females started to decrease during July and August, slightly increase again in September, then redecreased in the following months of the first growing season. In the second growing season, the obtained results showed also the same trend for gravid adult females population, somewhat became slightly higher than that of the first growing season (Table 2 and Figures $1 \& 2$ ). From the above-mentioned results, it could see that the estimated densities of fluctuating population of the black olive scale, S. oleae on olive trees under irrigation system proved two peaks for each. It could be concluded that this soft scale insect has two generations per year according to the immature stage appearance. The first limited from $1^{\text {st }}$ May to $1^{\text {st }}$ July with a peak in $1^{\text {st }}$ June and the second one from early July to October with a peak in $1^{\text {st }}$ August in both 
growing seasons (Fig. 3). The seasonal variations in population densities of $S$. oleae are shown in Table (3) and illustrated in. The data revealed the highest population density of collected individuals was observed during summer months in two successive years, comprised 55.8 and $55.0 \%$ of total counted individuals, respectively. The recorded seasonal densities of the olive black scale can be arranged ascending as follows: winter, autumn, spring and summer season in both two growing seasons.

These data agreed with those obtained by Peleg (1965) who reported that $S$. oleae has one generation on olive grown within unirrigated system, while there were two generations on irrigated olive farm. Also, Badary (2002) reported that the insect has two annual generations per year. Moreover, Badary (2010) reported that the population reached the maximum during mid of August and mid of September. These finding also agreed with those obtained by Souza et al. (2015) who reported that the greater abundance of the black scale insect was in spring and summer months, but hey recorded three generation/ year on olive grown under irrigation system.

The deduced results of the correlated monthly values of the weather factors (daily mean temperature $\left[{ }^{\circ} \mathrm{C}\right]$, relative humidity [\%] and wind speed $[\mathrm{m} / \mathrm{sec}]$ ) with total count of $S$. oleae individuals on olive trees under irrigation during elapsed period of 2017-2019 are exhibited in Table 4. The results show the significant positive relationship ( $r=0.768 \& 0.715)$ between daily mean temperature and estimated population density of $S$. oleae in both growing seasons, respectively. Barrede (2007) found that population of the black scale insect did not increase during certain periods due to the effect of low temperature on the first instar survival and the lower fertility of adult females. Also, the assessed simple correlation values, the estimated monthly means of relative humidity (\%) and the total count of $S$. oleae showed the weak insignificant negative relationship in the first season and insignificant relationship in the second season ( $r=0.112 \& 0.245$, respectively).

On the other hand, the data in Table 4 showed that the simple correlation of total counted individuals of olive black scale with wind speed expressing an insignificant positive relationship in the first growing season ( $r=0.22)$, but in the second season it showed a highly positive significant relationship ( $r=0.538 \& b=$ 3.017 ), indicated that the increase of wind speed by one unit, the population increased by three units and vise versa. That is due to the transference of the crawlers and early nymphs by the wind from another plant and/or places.

The results agreed with those obtained by Badary (2002) who found that temperature had a highly significant effect on the population density. Wind speed and relative humidity were found to be insignificant but in the second year of study the wind speed had highly significant effect. 
Table (3). Seasonal variations in estimated population density of S. oleae on olive tree in Matrouh during two successive growing seasons

\begin{tabular}{ccccc}
\hline \multirow{2}{*}{ Season } & \multicolumn{2}{c}{$\mathbf{2 0 1 7 / 2 0 1 8}$} & \multicolumn{2}{c}{$\mathbf{2 0 1 8 / 2 0 1 9}$} \\
\cline { 2 - 5 } & $\begin{array}{c}\text { No. of } \\
\text { individuals }\end{array}$ & $\begin{array}{c}\text { \% } \\
\text { for each } \\
\text { season }\end{array}$ & $\begin{array}{c}\text { No. of } \\
\text { individuals }\end{array}$ & $\begin{array}{c}\text { \% for each } \\
\text { season }\end{array}$ \\
\hline Spring & 6693 & 19.9 & 6928 & 19.7 \\
Summer & 18773 & 55.8 & 19310 & 55.0 \\
Autumn & 6085 & 18.1 & 6585 & 18.8 \\
Winter & 2025 & 6.2 & 2294 & 6.5 \\
\hline Total & $\mathbf{3 3 5 7 6}$ & 99.8 & $\mathbf{3 5 1 1 7}$ & 100 \\
\hline
\end{tabular}

Table(4). Simple correlations ( $r$ ) values between three ubrotic factors with their significance levels on total count of $S$.oleae on olive trees at Matrouh, Egypt. In two growing seasons

\begin{tabular}{|c|c|c|c|c|c|c|}
\hline \multirow{2}{*}{ Factors } & \multicolumn{3}{|c|}{$2017 / 2018$} & \multicolumn{3}{|c|}{$2018 / 2019$} \\
\hline & $\mathbf{r}$ & d.f(n-2) & $\mathbf{t}$ & $\mathbf{r}$ & d.f(n-2) & $\mathbf{t}$ \\
\hline $\begin{array}{l}\text { Daily mean } \\
\text { Temperature(c) }\end{array}$ & 0.768 & 22 & $8.76^{* *}$ & 0.715 & 22 & $4.80^{* \star}$ \\
\hline $\begin{array}{l}\text { Relative } \\
\text { humidity(\%) }\end{array}$ & 0.112 & 22 & 0.6 & 0.245 & $\begin{array}{l}2 \\
2\end{array}$ & 1.19 \\
\hline Wind speed (m/sec) & 0.22 & 22 & 1.06 & 0.538 & 22 & $3.54^{* *}$ \\
\hline
\end{tabular}

\section{REFERENCES}

Badary, Hoda A. M. (2002). Integrated pest management of Mediterranean black scale insect, Saissetia olea (Hemiptera, Coccidae) on olive tree. Ph.D. Thesis, Faculty of Agric. Moshtohor, Zagazig Univ.

Badary, Hoda A. M. (2010). Ecological aspects of Sassetia spp. (Coccidae: Coccoidae: Hemiptera) and their natural enemies in Egypt. Egypt. Acad. J. biolog. Sci., 4 (1): 163-174.

Ben-Dov, Y. and C. J. Hodgson (1997). Collecting and mounting. In: World crop pests, soft scale Insects, their Biology, Natural enemies and Control. Ben-Dov and C. J. Hodgson (Ed.), Volume 7A, pp.389-395. Elsevier sciences, Amsterdam, Netherlands.

Ben-Dov, Y., D. R. Miller and G.A.P. Gibson (2010). A systematic catalogue of the scale insects of the world. (http://www.sel.barc.usda.gov/ scalenet/scalenet.htm).

Bodenheimer, F. S. (1951). Description of some new genera of Coccoidea. Entomologische Berichten. Amsterdam, 13: 328-331.

Boulabiad, Mariam A. H. (2010). Studies on scale insects and mealybugs of deciduous and evergreen fruit trees in northern west coast of Egypt and their natural enemies. Ph. D. Thesis, Faculty of Agric. (Saba Basha), Alexandria Univ. Egypt. 
Delrio, G. and C. Foxi (2010). Current status of Saissetia oleae biological control in Sardinia (Italy). - IOBCMNRS Bulletin, 59: 171-176.

Haber, G. and D. Mifsud (2007). Pests and diseases associated with olive trees in the Maltese Islands (Central Mediterranean). The Central Mediterranean Naturalist, 4 (3):143-161.

Hall,W. J. (1922). Observation on the Coccidae of Egypt .Ministry Agric. Egypte, Tech. Sci. Serv.Bull. 22.

Haniotakis, G. E. (2005). Olive pest control: Present status and prospects. In:Proceedings of the IOBCMPRS Conference on Integrated Protection of Olive Crops. Chania, Crete.

Hodgson, C. J. (1994). The scale insect family Coccidae: an identification manual to genera. CAB Inter., Wallingford, Oxon, UK. 639 pp.

Ilias, Faiza and Fatiha Hammadi (2017). Population dynamics of Saissetia oleae (Olivier) (Hemiptera: Coccidae) on Olives. Open Access Library Journal, 4: e3805.

Mohammad, Z. K. and M. W. Ghabbour (2008). Updating list of Superfamily Coccoidea (Hemiptera) as known to exist in Egypt. J. Egypt-German Soc. Zool. Entomol., 56E: 147-162.

Morillo, C. (1977). Morfología y biología de Saissetia oleae (Homoptera Coccidae). Boletín de la Real Sociedad Española de Historia Natural Sección Biológica 75: 87-108.

Peleg, B. A. (1965). Observation of the life cycle of the black scale Saissetia oleae Bern. on citrus and olive trees in Isreal. The Isreal J. Agric. Res., 15:21-26.

Souza, G. C., L. R. Redaelli and V. R. D. Wolff (2015). Population dynamics of Saissetia oleae (Hemiptera:Coccidae) on olive trees. Rev. Bras. Frutic.,37(4):852-858. 


\section{الملخص العربي}

\section{الكثافة العددية لحشرة الزيتون القشرية Sassetia oleae التي تصيب أثجار الزيتون في المزارع المروية في محافظة مطروح - مصر}

حسن علي عبدالحميد مصباح'، خديجة سبد مرسي'، ماجدة بهجت القاضي' ،

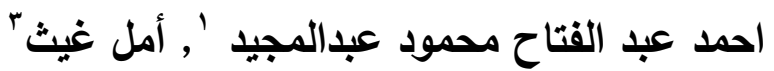

' قسم وقاية النبات - كلية الزراعة (سابا باشا) - جامعة الإسكندرية

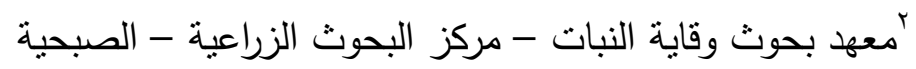

" قسم الحيوان كلية الآداب والعلوم (درنة) - جامعة عمر المختار - ليبيا

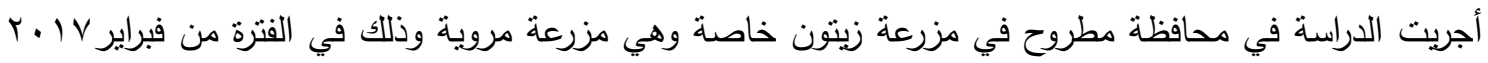
حتى فبراير 9 1. الدراسة التعداد الكلي لحشرة الزيتون القثرية خلال عامين متتاليين وكدلك التوزيع الفصلي للأطوار المختلفة وتأثير ثلاثة عوامل جوية (الحرارة والرطوبة النسبية وسرعة الرياح) على تعداد الحشرة. قدأظهرت النتائج المتحصل عليها أن هناك ب فترات لزيادة تعداد الحشرة خلال عامين وذللك في موسمى الربيع والصيف. واتضح أن الأعمار غير الكاملة نتزايد في فترة الخريف والثتاء في كلا العامين , بينما نتلغ الاناث أعلى نسبة خلال شهر سبتمبر ، وتزيد نسبة الاناث الحاملة للبيض خلال الفترة مارس- يوليو في كلا العامين. كما بينت النتائج أن للحشرة جيلين في السنة خلال شهري يونيو وأغسطس. وقد أظهرت النتائج أن نسبة تعداد الحشرة تكون أعلى ما يمكن في فصل الصيف يليه الربيع ثم الخريف وأقل تعداد تم تسجيله خلال فصل الثتاء. وبالتحليل الإحصائي وجد أن درجة الحرارة لها تأثنير معنوي موجب على تعداد الحشرة بمعنى كلما ارتفعت درجة الحرارة ازداد

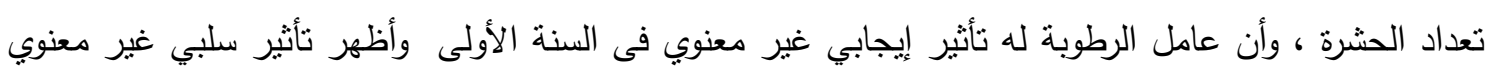

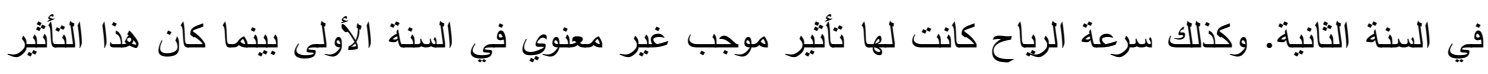
معنوياً في السنة الثانية. 